University of Nebraska - Lincoln

DigitalCommons@University of Nebraska - Lincoln

Publications, Agencies and Staff of the U.S.

Department of Commerce

U.S. Department of Commerce

$1-2000$

\title{
Harbor Porpoise (Phocoena phocoena) Abundance in Alaska: Bristol Bay to Southeast Alaska, 1991-1993
}

M. Dahlheim

Alaska Fisheries Science Center, National Marine Mammal Laboratory

A. York

Alaska Fisheries Science Center, National Marine Mammal Laboratory

R. Towell

Alaska Fisheries Science Center, National Marine Mammal Laboratory

J. Waite

Alaska Fisheries Science Center, National Marine Mammal Laboratory

J. Breiwick

Alaska Fisheries Science Center, National Marine Mammal Laboratory

Follow this and additional works at: https://digitalcommons.unl.edu/usdeptcommercepub

Part of the Environmental Sciences Commons

Dahlheim, M.; York, A.; Towell, R.; Waite, J.; and Breiwick, J., "Harbor Porpoise (Phocoena phocoena) Abundance in Alaska: Bristol Bay to Southeast Alaska, 1991-1993" (2000). Publications, Agencies and Staff of the U.S. Department of Commerce. 173.

https://digitalcommons.unl.edu/usdeptcommercepub/173

This Article is brought to you for free and open access by the U.S. Department of Commerce at DigitalCommons@University of Nebraska - Lincoln. It has been accepted for inclusion in Publications, Agencies and Staff of the U.S. Department of Commerce by an authorized administrator of DigitalCommons@University of Nebraska - Lincoln. 


\title{
HARBOR PORPOISE (PHOCOENA PHOCOENA) ABUNDANCE IN ALASKA: BRISTOL BAY TO SOUTHEAST ALASKA, 1991-1993
}

\author{
M. Dahlheim \\ A. YORK \\ R. TOWELL \\ J. WAITE \\ J. BREIWICK \\ Alaska Fisheries Science Center, \\ National Marine Mammal Laboratory, \\ 7600 Sand Point Way N. E. BIN C15700, \\ Seattle, Washington 98115 , U.S.A. \\ E-mail: marilyn.dahlheim@noaa.gov
}

\begin{abstract}
Between 1991 and 1993, Alaska harbor porpoise (Pbocoena phocoena) abundance was investigated during aerial surveys throughout much of the coastal and offshore waters from Bristol Bay in the eastern Bering Sea to Dixon Entrance in Southeast Alaska. Line-transect methodology was used, and only those observations made during optimal conditions were analyzed. Survey data indicated densities of 4.48 groups $/ 100 \mathrm{~km}^{2}$, or approximately 3,531 harbor porpoises (95\% C.I. 2,206-5,651) in Bristol Bay and 0.54 groups $/ 100 \mathrm{~km}^{2}$, or 136 harbor porpoises (95\% C.I. 11-1,645) for Cook Inlet. Efforts off Kodiak Island resulted in densities of 1.85 groups $/ 100 \mathrm{~km}^{2}$, or an abundance estimate of 740 (95\% C.I. 259-2,115). Surveys off the south side of the Alaska Peninsula found densities of 2.03 groups $/ 100 \mathrm{~km}^{2}$ and an abundance estimate of 551 (95\% C.I. 423-719). Surveys of offshore waters from Prince William Sound to Dixon Entrance yielded densities of 4.02 groups $/ 100 \mathrm{~km}^{2}$ and an abundance estimate of 3,982 (95\% C.I. 2,567-6,177). Combining all years and areas yielded an uncorrected density estimate of 3.82 porpoises per $100 \mathrm{~km}^{2}$, resulting in an abundance estimate of 8,940 porpoises $(\mathrm{CV}=$ $13.8 \%$ ) with a $95 \%$ confidence interval of $6,746-11,848$. Using correction factors from other studies to adjust for animals missed by observers, the total number of Alaska harbor porpoises is probably three times this number.
\end{abstract}

Key words: harbor porpoise, Phocoena phocoena, abundance, Alaska.

Under the recently reauthorized U.S. Marine Mammal Protection Act (16 U.S.C. 1361-1421h) incidental mortality of marine mammals that interact with commercial fisheries is to be managed such that removals do not exceed 
a level referred to as the Potential Biological Removal (PBR) level (Barlow et al. 1995).

Although harbor porpoises, Phocoena phocoena, are known to occur throughout Alaska waters (Fiscus et al. 1976; Leatherwood and Reeves 1978; Lowry et al. 1982a, b; Leatherwood et al. 1983), few estimates of abundance exist. Aerial surveys conducted in the late 1970s in Prince William Sound (Hall, $1979)$ resulted in a summer population estimate of 946 harbor porpoises $(95 \%$ confidence interval of 820-1,159). However, because the harbor porpoise was not the target species, this is probably an underestimate of harbor porpoise abundance. Leatherwood et al. (1983) conducted aerial surveys of cetaceans throughout the eastern Bering Sea and Shelikof Strait and reported 62 sightings of groups of harbor porpoises, representing 100 individuals. Using only those sightings collected during random transects (= 45 sightings), Leatherwood $e t$ al. (1983) reported a density estimate of $0.38 \pm 0.109$ porpoises per $100 \mathrm{~km}^{2}$ for the eastern Bering Sea and $2.185 \pm 8.5$ porpoises per $100 \mathrm{~km}^{2}$ for Shelikof Strait. The only study in Alaska designed specifically to count harbor porpoises was conducted from a shore-based site in Glacier Bay in Southeast Alaska (Taylor and Dawson, 1984). Densities of harbor porpoises varied by season and region within Glacier Bay from 1.2 to 5.9 groups $/ 100 \mathrm{~km}^{2}$.

Braham et al. (1983) plotted harbor porpoise sighting data from NOAA's

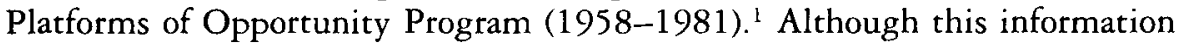
is valuable with respect to knowledge of overall distribution of harbor porpoises, the sighting data were opportunistic and not useful for estimating abundance or trends in population size. Additional surveys which reported sightings of harbor porpoises in Alaska include Forsell and Gould (1981) for the Kodiak area and Brueggeman $(1987,1988)$ for the Aleutian Islands.

Even less is known about the seasonal movements of Alaska harbor porpoises or the amount (if any) of genetic exchange that may occur between geographical areas, that is, the relative discreteness of stocks. Based on geographical considerations, Gaskin (1983) proposed that harbor porpoises inhabiting the Bering Sea and adjacent Arctic waters be considered provisionally as three discrete subpopulations. Gaskin also proposed that harbor porpoises from the Gulf of Alaska and eastern North Pacific be divided into three stocks. Yurick (1977) suggested that there were three eastern Pacific subpopulations based on skull morphometric studies. Preliminary genetic studies on harbor porpoises occurring in California, Washington State, and Alaska waters indicated some isolation among porpoises inhabiting these geographical regions suggesting separation with little, if any, current interchange (Rosel et al., 1995). ${ }^{2}$ During the present study it was not fiscally possible to survey all areas of the state in any one year. Accordingly, we selected sections of the state to survey in consecutive years to maximize the likelihood of including all of the animals

\footnotetext{
${ }^{1}$ Opportunistic sighting database operared by Alaska Fisheries Science Center, National Marine Mammal Laboratory, 7600 Sand Point Way NE, Seattle, Washington 98115.

${ }^{2}$ Personal communication from A. Dizon, Southwest Fisheries Science Center, P. O. Box 271, La Jolla, CA 92038, U.S.A., December 1998
} 


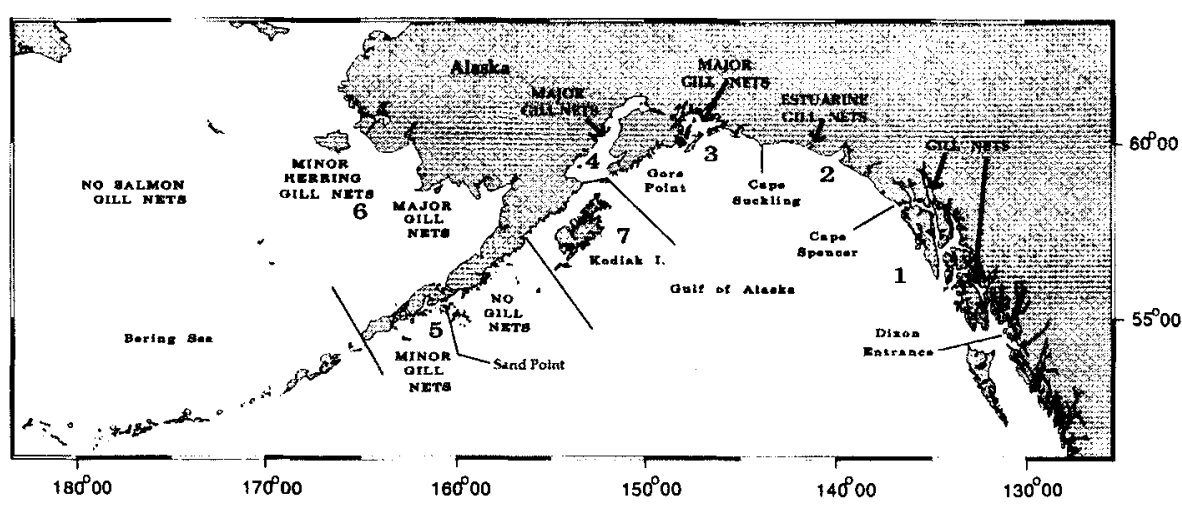

Figure 1. Survey areas for Alaska harbor porpoise (Pbocoena phocoena) assessment studies.

for a particular area surveyed while minimizing the likelihood of significant movement between areas among survey years. We believe that harbor porpoises do not make long-range movements either within seasons or between years, and certainly not in the order of magnitude (several thousands of miles in some cases) needed to interfere with the estimation of abundance among surveyed areas in Alaska. Further tagging work is needed to assess the seasonal distribution of harbor porpoises and to assess what impact, if any, seasonal movements have on estimating abundance in adjacent sampling areas among years. Until further research is conducted, harbor porpoise stock structure in the eastern North Pacific is unclear.

There are no directed fisheries for harbor porpoises in Alaska. However, because harbor porpoises are distributed in coastal waters, they are expected to be caught incidental to commercial and subsistence net-fishing operations (an authorized form of take under the MMPA). Matkin and Fay (1980) reported that the take some $20 \mathrm{yr}$ ago was not significant (Copper River Delta). The nature and magnitude of the current incidental take is unknown.

In 1991 the National Marine Mammal Laboratory initiated a 3-yr study on Alaska harbor porpoises. The objectives of this program were to: (1) Obtain minimum population estimates in coastal waters using line transect merhodology with a coefficient of variation for density estimates of less than $30 \%$ for each survey area. (2) Establish a baseline for detecting changes in abundance through time, for analysis of trends.

\section{Materials and Methods}

\section{Study Areas}

The nearshore waters of Alaska were divided into seven areas for survey purposes (Fig. 1). The study areas included waters where nearshore fisheries could interact with harbor porpoises. Area 1 included the outer waters of 
Southeast Alaska; Area 2, the Alaska Panhandle; Area 3, Prince William Sound and adjacent waters; Area 4, Cook Inlet; Area 5, the south side of the Alaska Peninsula; Area 6, Bristol Bay; and Area 7, the Kodiak Archipelago. The Aleutian Islands and Bering Sea areas (outside of Bristol Bay) were not included, because there are currently no commercial nearshore net fisheries present that might incidentally take harbor porpoises. In our analyses, Areas 1, 2, and 3 were combined (Dixon Entrance to Prince William Sound).

Because the amount of coastline to be surveyed was large (over 4,800 straight-line kilometers), each annual aerial survey was designed to cover only two to three of the seven areas; over the 3-yr period all seven areas were surveyed: in 1991, Areas 4 and 6; in 1992, Areas 5 and 7; in 1993, Areas 1, 2, and 3. Concurrent with the 1993 aerial surveys of the offshore waters of Southeast Alaska, a vessel survey was also conducted to assess harbor porpoise abundance within the inland waterways of Southeast Alaska. Details of this survey are reported in Dahlheim et al. (1994).

\section{Field Metbodology}

A Twin Otter ${ }^{3}$ was used as the survey platform. The surveys were flown at an altitude of $152.5 \mathrm{~m}(500 \mathrm{ft})$ and at an airspeed of $100 \mathrm{kn}$. Four biologists rotated through 40-min shifts: from left-side observer to the recorder position, to right-side observer, and then to the rest position. This resulted in two hours on duty with a 40-min rest period. Bubble windows behind the cockpit allowed observers to see directly below the aircraft. The recorder sat near the back of the plane and entered observation data into a portable computer. The plane was equipped with an intercom system allowing the survey crew to communicate with each other and the pilots.

A Trimble 3000 Global Positioning System ${ }^{3}$ (GPS) unit was connected directly to the computer (a Loran system was used in 1991). Once per minute, or whenever data were manually entered, the date, time, and position (from Loran or GPS) were automatically recorded. Time spent on effort was recorded by marking the beginning and end of transect lines. At the beginning of every transect line, or whenever a change occurred, the recorder noted observer positions and weather conditions, including percent cloud cover, Beaufort state, and glare and visibility conditions on each side of the aircraft.

The left and right side observers scanned horizontally from directly in front of the plane $\left(0^{\circ}\right)$ to $90^{\circ}$ off the left or right side. Vertically, they scanned from the horizon to directly below the plane. A small overlap between observers occurred directly beneath the plane, which reduced the chance of missing animals on the trackline. Communication among observers prevented double counting of animals sighted in that overlap. When a porpoise sighting occurred, the observer called out "mark" as the aircraft wing crossed the sighting location, alerting the recorder to mark the time of the sighting. The species, group size, and vertical angle (via a Sunto ${ }^{3}$ inclinometer) were then reported

\footnotetext{
${ }^{3}$ Reference to trade names does not constitute endorsement by NMFS.
} 
to the recorder. Sightings made by the recorder, resting team member, or pilots were recorded after the primary recordings as "off-effort" and were not used in density estimate calculations. In addition, sightings made during transit to and from transect lines were noted but not included in our analysis.

In 1991 a single zigzag trackline was flown across Cook Inlet, a single sawtooth trackline was flown along the north side of Bristol Bay, and three identical saw-tooth tracklines were flown along the entire length of the south side of Bristol Bay (Fig. 2). The length of each saw-tooth was approximately 27.8 $\mathrm{km}(15 \mathrm{nmi})$ per side. To extend coverage into deeper waters, after every third

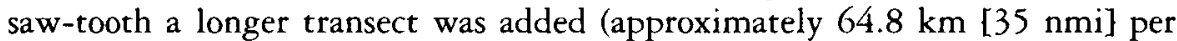
side). Surveys were also flown across the middle of Bristol Bay. In 1992 and 1993 three independent surveys of the offshore waters of the Alaska Peninsula, Kodiak Island, and Southcentral and Southeast Alaska were completed (Fig. 2). Again three saw-tooths $(27.8 \mathrm{~km}$ in length) were followed by a longer saw-tooth $(64.8 \mathrm{~km}$ in length). However, each set of lines was offset from the others by an equal distance, creating an overlap of saw-tooths. The starting position of each replicate trackline was determined by choosing three random numbers between 0 and 37 , the width of the saw-tooth (base width of 37 $\mathrm{km}$ ). By offsetting three different tracklines rather than surveying one trackline three times, we were able to reverse course and continue surveying on a different set of lines in the same day, remaining independent of the previous line surveyed. Each sampled survey line was independent of the other for purposes of pooling trackline results. The same airplane was used throughout the study period, and the teams of observers overlapped considerably among years.

\section{Data Analysis}

Estimation methods - Density of harbor porpoises was calculated using line transect estimates based on perpendicular distances of sightings to the cruise track of the airplane. The estimate of the density of groups $\left(D_{g}\right)$ in the study area was

$$
D_{g}=\frac{n \hat{f}(0)}{2 L}
$$

where $L$ was the length of the trackline, $\hat{f}(0)$ was the value of the detection curve evaluated at zero distance off the trackline, and $n$ was the number of sightings. The total number of animals per unit area was estimated by multiplying the estimate of the density of groups by the estimate of the average group size $(\bar{s})$-that is, the estimate of density $(D)$ was

$$
\hat{D}=\frac{n \hat{f}(0) \bar{s}}{s L}
$$

where $n / L$ was the number of sightings per length of trackline and $\bar{s}=$ average group size. The variance of this estimate (Buckland et al. 1993, Burnham et al. 1980) has components of $\hat{f}(0), \vec{s}$, and the encounter rate $(n / L)$. If $\hat{f}(0), \bar{s}$ 


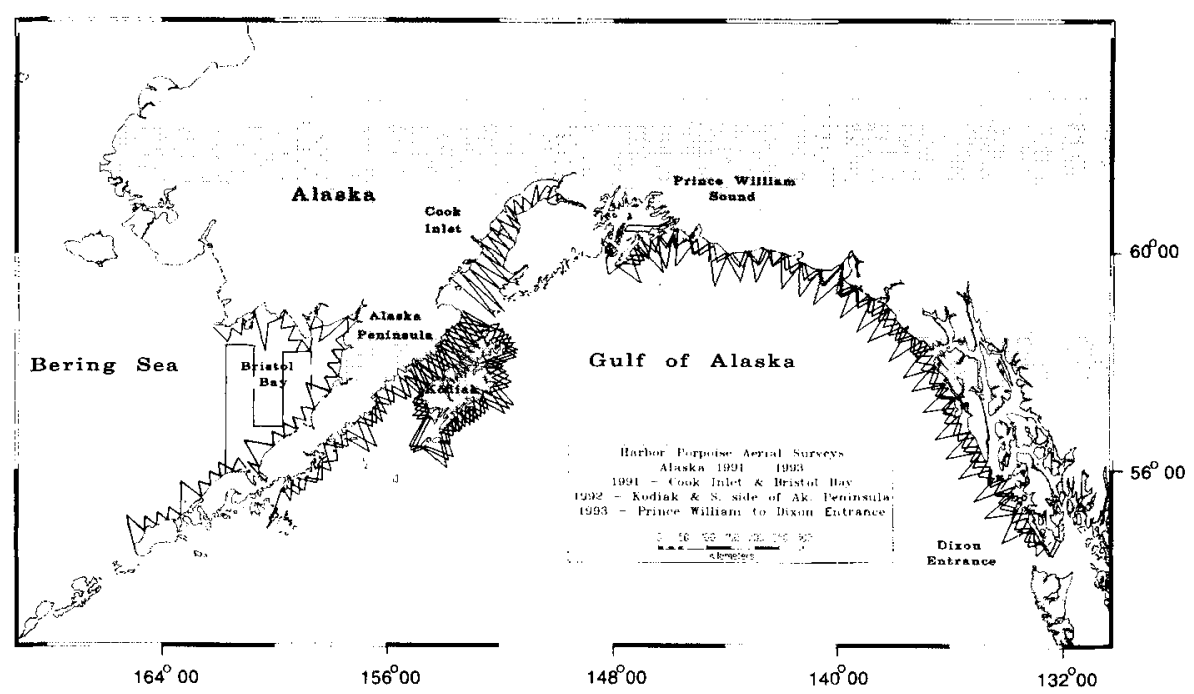

Figure 2. Aerial survey tracklines for harbor porpoise (Phocoena phocoena) assessment studies (1991-1993).

and the encounter rate are independent, and no animals on the trackline are missed, then,

$$
\operatorname{var}(\hat{D})=\hat{D}^{2}\left[\frac{\operatorname{var}(\hat{f}(0))}{\hat{f}(0)^{2}}+\frac{\operatorname{var}(n / L)}{(n / L)^{2}}+\frac{\operatorname{var}(\bar{s})}{\bar{s}^{2}}\right]
$$

Metbods for measuring perpendicular distance-The distance from a sighting to the trackline of the airplane was calculated as $h / \tan \left(\boldsymbol{\alpha}_{s}\right)$, where $\boldsymbol{\alpha}_{s}$ is the sighting angle and $b$ is the survey altitude $(152.5 \mathrm{~m})$.

Metbods for estimating density-For our estimation of population density, we used the program DISTANCE (Laake et al. 1993). In applying the line transect method it is necessary to assume that the perpendicular distances are measured without error. Measurement errors do occur because observers sometimes round off sighting angles, and it is difficult to measure large radial distances accurately. Therefore, we followed the suggestions of Buckland (1985) and Burnham et al. (1980) and grouped the perpendicular distances into intervals. Although this technique will often increase the estimate of the variance, it should reduce bias associated with rounding off angle measurements, especially at $0^{\circ}$. We also followed Burnham et al. (1980) and truncated 3\% of the extreme distances as a bias-reduction technique.

Detection curves were calculated for all data collected in each survey year by pooling all sightings in a given year. Since $\hat{f}(0)$ did not differ between years, and since the estimated detection curves were similar, one detection curve was computed from the pooled data and a single estimate of $\hat{f}(0)$ obtained. Encounter rates $(n / L)$ and mean group size $(\bar{s})$ were estimated separately for each area using the methods of Buckland $e t$ al. (1993) as implemented in Laake et al. (1993). 
The variance of the density estimate has three components: the variance of $\hat{f}(0)$, of the encounter rate $n / L$, and of group size (variances were estimated using both maximum likelihood and bootstrap methods). In the maximum likelihood approach the variances of $\hat{f}(0)$ and $\bar{s}$ were obtained using the methods described in Buckland et al. (1993) as implemented in Laake et al. (1993). The variance of the encounter rate was estimated from the variation in encounter rates between replicates if there were replicate tracklines, or by assuming that the number of encounters followed a Poisson distribution $(\operatorname{var}(n)=$ $n$ and $\left.\operatorname{var}\left(n / L^{2}\right)=n / L^{2}\right)$ if there was only one replicate. The bootstrap estimates of the variances were obtained by computing the empirical variance of 2,000 replicates of the above process. In addition, we computed a second bootstrap estimate of the variance of the encounter rate by subsampling survey legs with replacement within each sampling area. A survey leg is a segment of effort in which all recorded survey variables (observers, Beaufort state, glare, visibility) were identical. The subsampling process assumed that the legs were independent. Subsampling was conducted in such a way that the total length of the bootstrap sample was similar (i.e., legs were drawn until the total sampled distance exceeded the observed distance). The last sampled leg was used in the bootstrap if the total distance was nearer the observed distance than the total length without the last leg; otherwise the last sampled leg was not used to obtain the observed value of $L$.

The size of the study area was measured from a digitized map of Alaska using the software CAMRIS. ${ }^{3,4}$

Combined abundance estimates for the State of Alaska-The abundance estimates derived for each geographical area surveyed by aircraft during our study were summed to obtain a total abundance estimate of harbor porpoises for Alaskan waters from Bristol Bay (Southeast Bering Sea) to Dixon Entrance (in Southeast Alaska).

\section{Results}

\section{Detection Curves}

We followed the advice of Buckland et al. 1993 and investigated a wide variety of models for our sighting data. Nine models were considered: the uniform, hazard rate, and half normal curves with either cosine, polynomial, or Hermite polynomial adjustments. The three models which best fit the data based on the Akaike Information Criterion (AIC) and chi-square goodness of fit criteria over several different groupings of data were the half-normal model with one cosine adjustment term, the hazard model with two Hermite polynomial adjustment terms, and the uniform model with two cosine adjustment terms (Fig. 3). The uniform and half-normal models produced similar estimates of $f(0)$ and effective strip width, while the hazard-rate model gave a smaller value of $\hat{f}(0)$ with a larger effective strip width. Based on the AIC and

\footnotetext{
${ }^{4}$ Computer Aided Mapping and Resource Inventory System. Ecological Consulting, Inc., Portland, Oregon.
} 


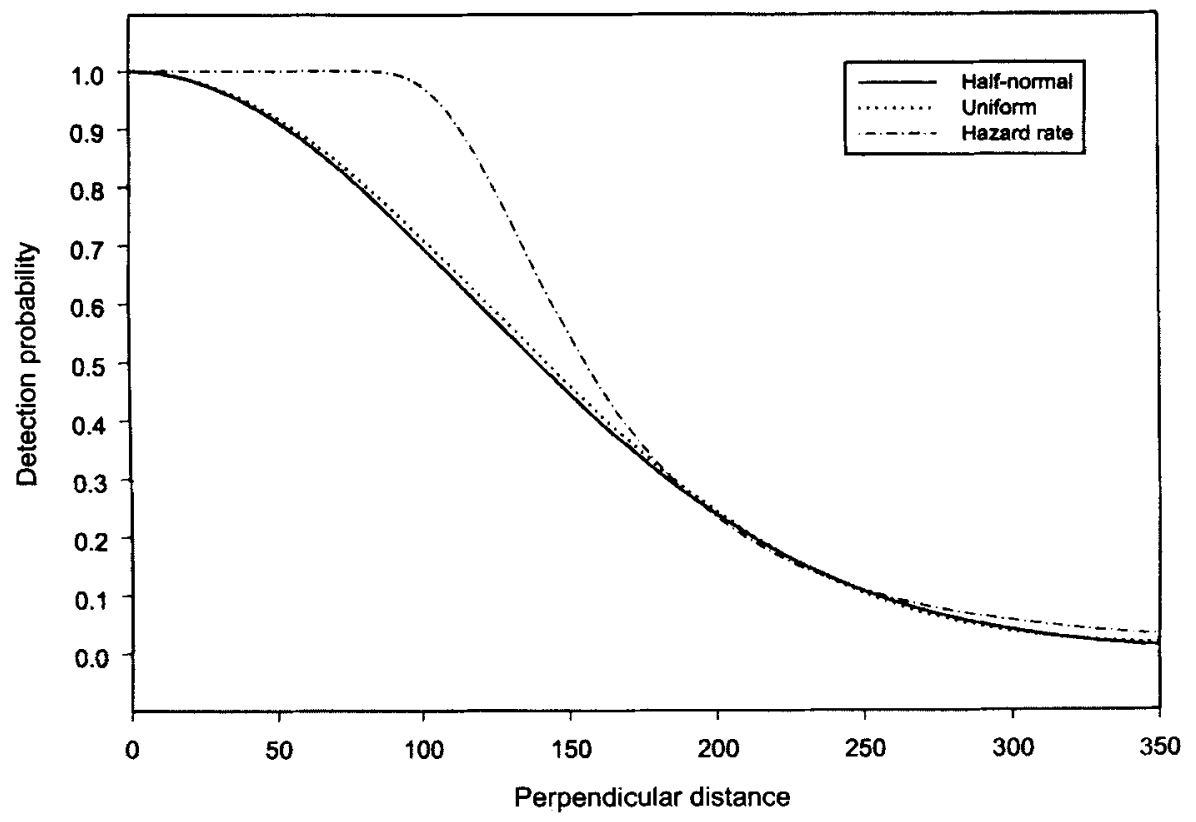

Figure 3. Half-normal, uniform, and hazard rate model detection curves fit to harbor porpoise sighting data.

chi-square over various groupings of the data, and the quality of the fit near 0 , we modeled the detection curve using the half-normal with one cosine adjustment.

The estimated values of $\hat{f}(0)$, effective strip width (ESW), and the probability of detecting porpoises if they were within the effective strip width $(P)$ using the maximum likelihood and bootstrap methods (Table 1,2 ) were not significantly different; the standard errors of $\hat{f}(0)$, ESW and $P$ from the maximum likelihood method were larger than the corresponding bootstrapped standard errors (compare Table 1, 2).

We examined size bias by testing the significance of the slope of the regression of the logarithm of school size on estimated detection probability. This resulted in a non-significant slope $(P=0.36, \mathrm{df}=177)$.

\section{Cook Inlet and Bristol Bay}

Aerial surveys were conducted in Cook Inlet on 1 and 2 August 1991 and Bristol Bay from 4 to 13 August 1991. In Cook Inlet 1,873 km were surveyed, resulting in three group sightings (four animals) (Fig. 4). In Bristol Bay, 5,725 $\mathrm{km}$ were surveyed and thirty-five groups (39 animals) were seen (Fig. 4). More porpoises (21 sightings) were seen during mid-bay (offshore) surveys than during nearshore surveys (seven sightings). Replicate surveys in coastal waters yielded similar results: seven, six, and five sightings, respectively. Average 


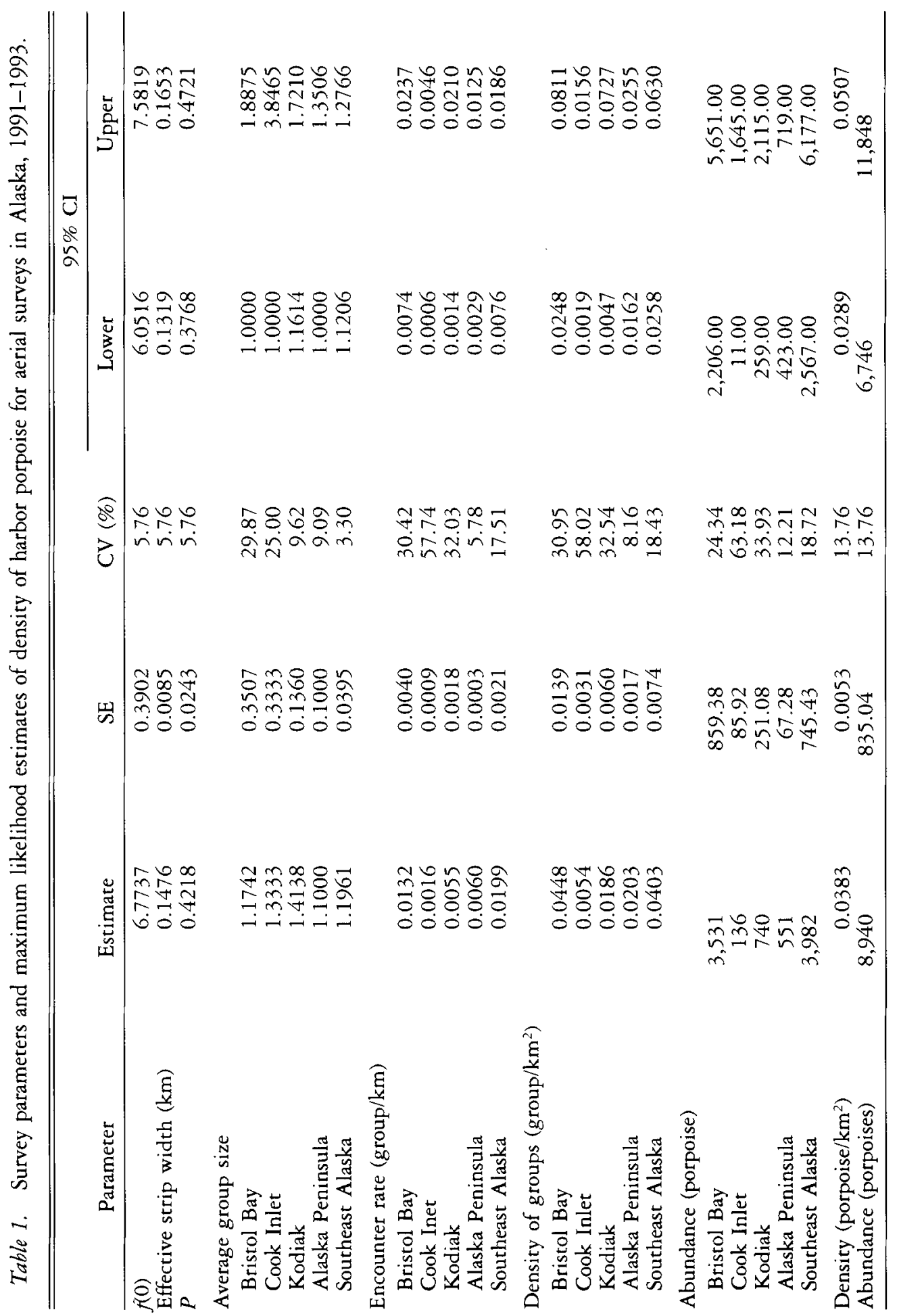


group size for Cook Inlet was $1.33(\mathrm{SE}=0.33)$. Average group size for Bristol Bay was $1.17(\mathrm{SE}=0.35)$.

We estimated the density in Cook Inlet to be 0.54 groups $/ 100 \mathrm{~km}^{2}(\mathrm{SE}=$ 0.31 ), resulting in an abundance estimate of 136 with a $95 \%$ confidence interval of $11-1,645 ; \mathrm{CV}=63.2 \%$ ). For Bristol Bay, a density estimate of 4.48 groups $/ 100 \mathrm{~km}^{2}$ was calculated ( $\mathrm{SE}=1.38$ ). A density estimate for the entire area was computed as the weighted sum of the separate density estimates, with weights equal to the proportion of the total area covered by each subarea. An abundance estimate of 3,531 was obtained $(\mathrm{CV}=24.3 \%)$ with a $95 \%$ confidence interval ranging from 2,206 to 5,651 .

The estimated encounter rates and, thus, the density of groups and the abundance estimates from the bootstrap calculations were similar to the likelihood values (compare Table 1,2). The bootstrapped standard errors of the encounter rates, group density, and abundance in Bristol Bay were slightly smaller than the likelihood estimates; for Cook Inlet they were virtually identical.

\section{Kodiak Island and the South Side of the Alaska Peninsula}

Aerial surveys were conducted off Kodiak Island and the south side of the Alaska Peninsula from 6 July to 9 August 1992. A total of $6,961 \mathrm{~km}$ was surveyed (Fig. 2). Forty sightings (54 animals) were made (Fig. 4). Waters surrounding Kodiak Island were surveyed three times. The saw-tooth tracklines along the south side of the Alaska Peninsula from the west end of Shelikof Strait to Sand Point were surveyed twice. Inclement weather prohibited surveying west of Sand Point. Average group size off Kodiak Island was 1.41 $(\mathrm{SE}=0.13)$ and off the south side of the Alaska Peninsula $1.1(\mathrm{SE}=0.10)$. We estimated the density off Kodiak Island to be 1.85 groups $/ 100 \mathrm{~km}^{2}$ (SE $=6.03$ ) for an abundance estimate of 740 with a $95 \%$ confidence interval of 259 to 2,115 and a coefficient of variation of $33.9 \%$. Density off the south side of the Alaska Peninsula was 2.03 groups $/ 100 \mathrm{~km}^{2}(\mathrm{SE}=1.65)$. The abundance estimate for this area was 551 with a $95 \%$ confidence interval of $423-719(\mathrm{CV}=12.2 \%)$

The estimated encounter rates from the bootstrap were similar to the likelihood estimates (Table 1,2). The level of variability of the bootstrapped Kodiak estimates was the same as for the likelihood estimates, but for the south side of the Alaska Peninsula, both bootstrapped estimates were much more variable $(\mathrm{CV}=8.16 \%$ vs. $32.6 \%$ and $31.6 \%)$. We believe this was probably caused by more clustering of porpoise schools in the Alaska Peninsula area. Thus, while the abundance estimates were similar, the bootstrapped confidence intervals were about twice as wide as those based on the likelihood method. This suggests that the assumptions for the likelihood-based variance estimates were not satisfied and that the bootstrap estimates may be more realistic. 


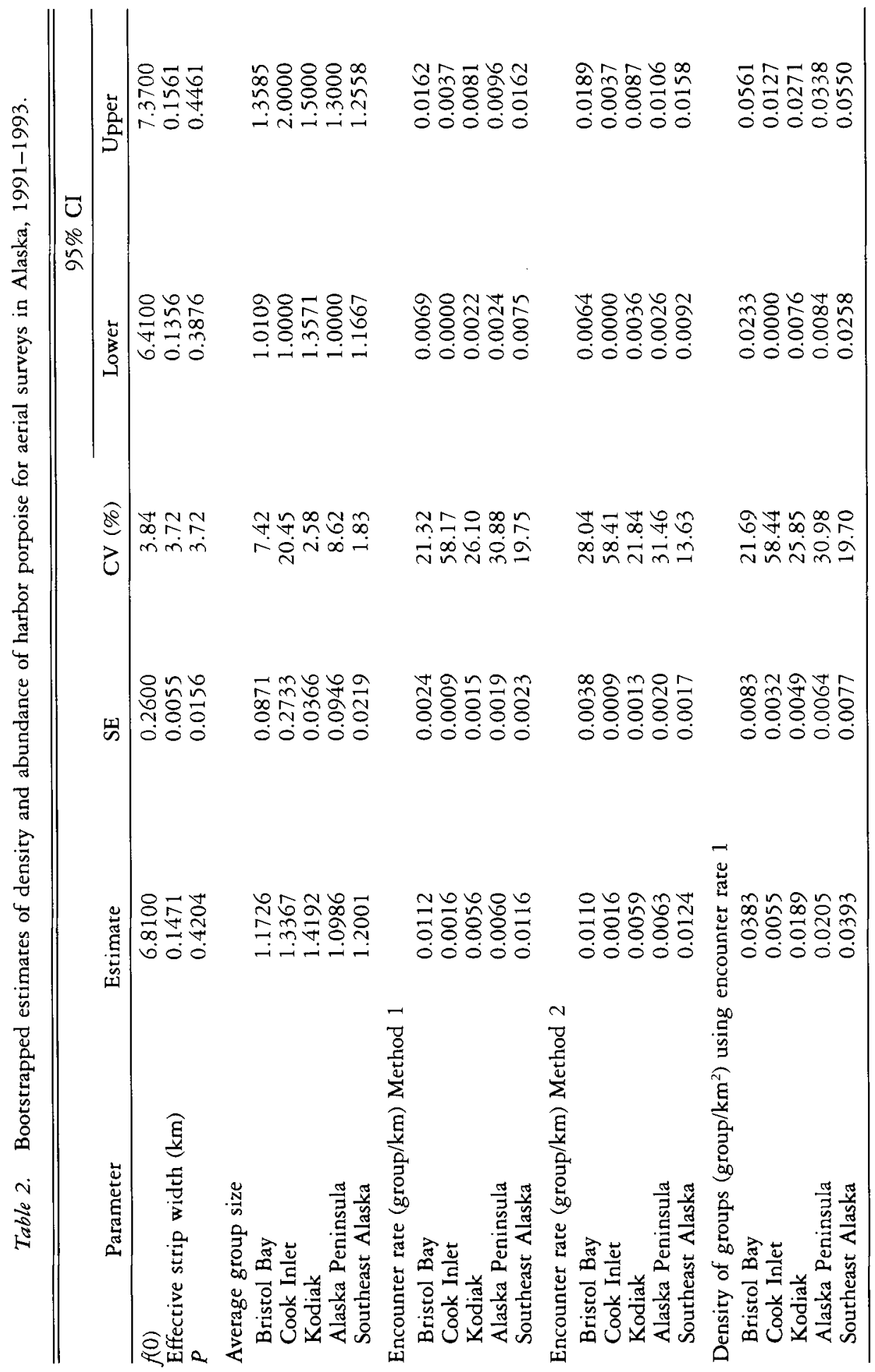




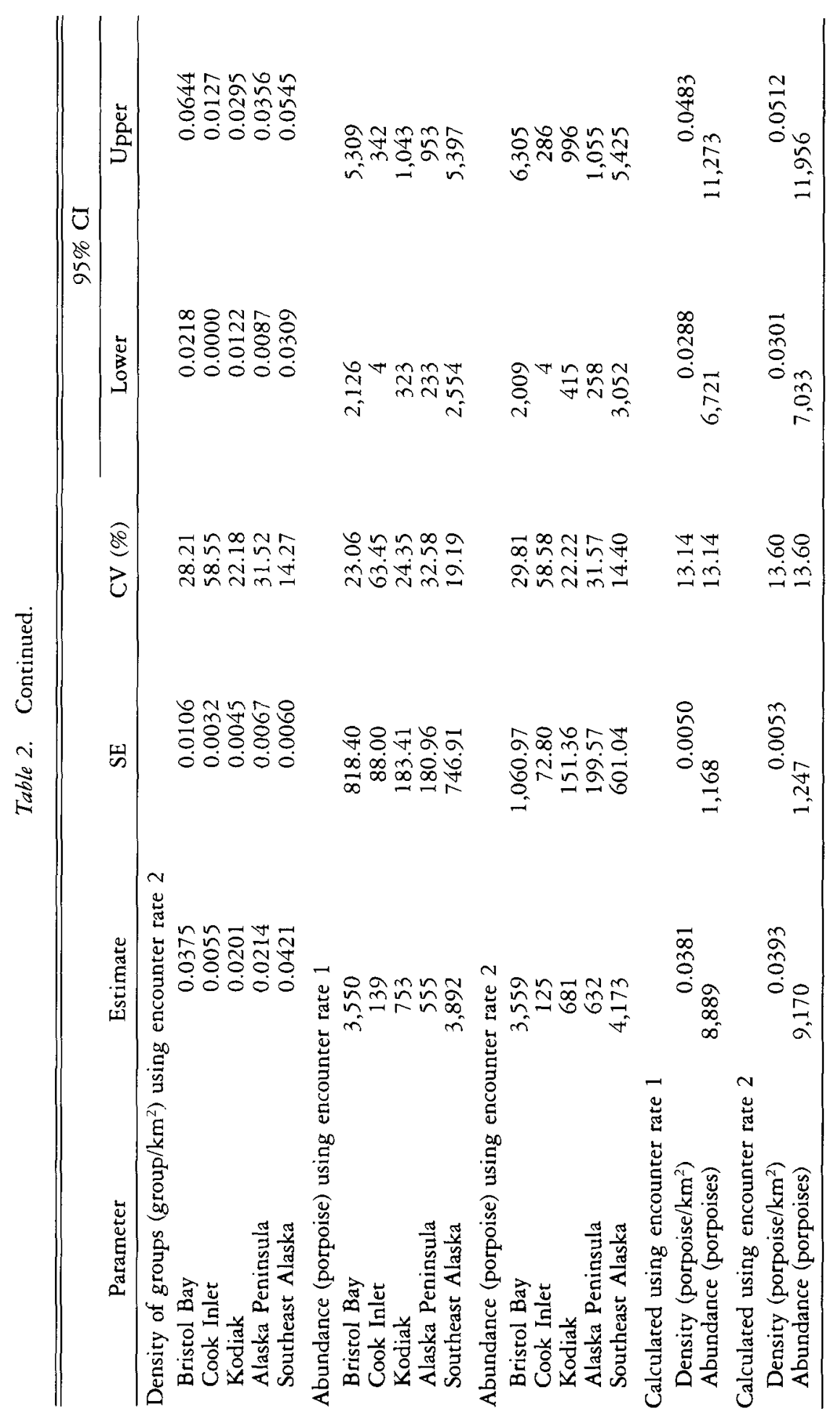




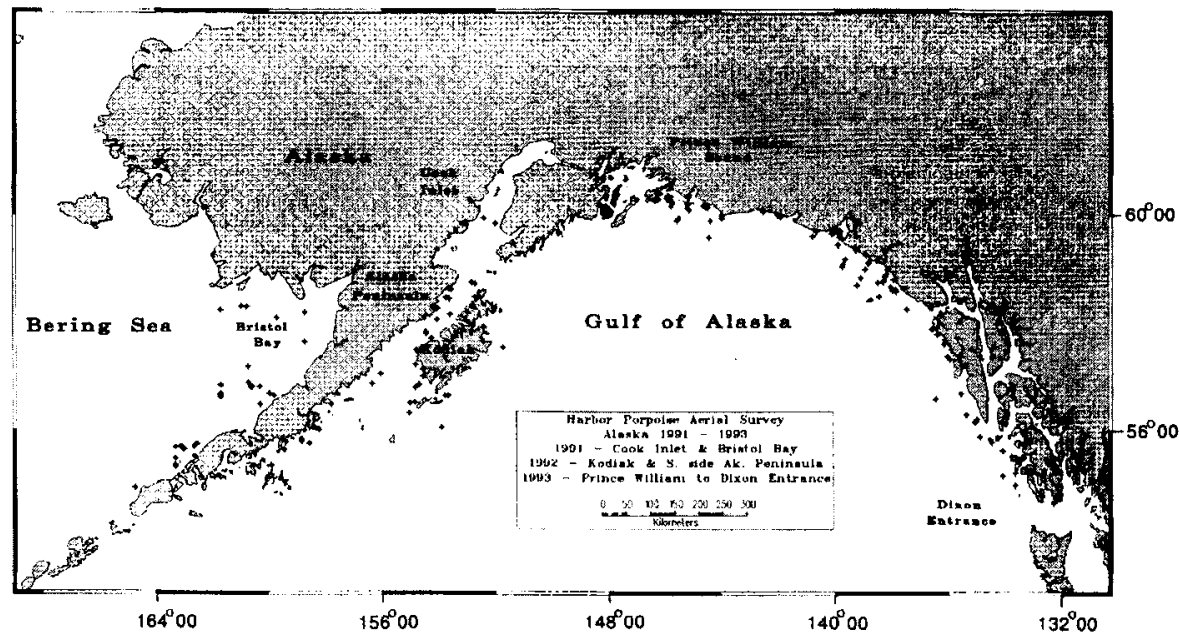

Figure 4. Sightings of Alaska harbor porpoises (Phocoena phocoena) based on aerial surveys (1991-1993).

\section{Prince William Sound to Dixon Entrance}

Aerial surveys were conducted from Prince William Sound to Dixon Entrance from 1 to 26 June 1993. A total of $8,573 \mathrm{~km}$ were surveyed (Fig. 2), and 105 groups (131 animals) were seen(Fig. 4). Average group size was 1.22 $(\mathrm{SE}=0.04)$. Density was calculated at 4.02 groups $/ 100 \mathrm{~km}^{2}(\mathrm{SE}=7.42)$. An abundance estimate of 3,982 was obtained with a $95 \%$ confidence interval of 2,567-6,177 (CV $=18.7 \%)$.

The estimated encounter rates based on the bootstrap were similar to the likelihood estimates, and the confidence intervals overlapped each other. The standard error using the likelihood method was smaller than the standard errors based on bootstrap methods 1 or 2. This is probably caused by little variability between replicates but high variability within the replicates, with most sightings occurring on very few legs.

\section{Overall Abundance Estimate for Alaska State Waters}

We combined the estimates obtained for the five geographical areas (areas 1, 2, and 3 were combined; Fig. 1) for all years (1991-1993), and included vessel surveys within the inside waters of Southeast Alaska that occurred simultaneously with aerial surveys conducted in June 1993 (estimate $=1,586$, $\mathrm{SE}=622$; Dahlheim et al. 1994). This resulted in an overall abundance estimate of $10,526(\mathrm{SE}=1,325)$ with a $95 \%$ confidence interval of 8,232 13,459 (Table 3 ). The calculated coefficient of variation was $12.6 \%$. sightings made during these aerial surveys are depicted in Figure 4. 


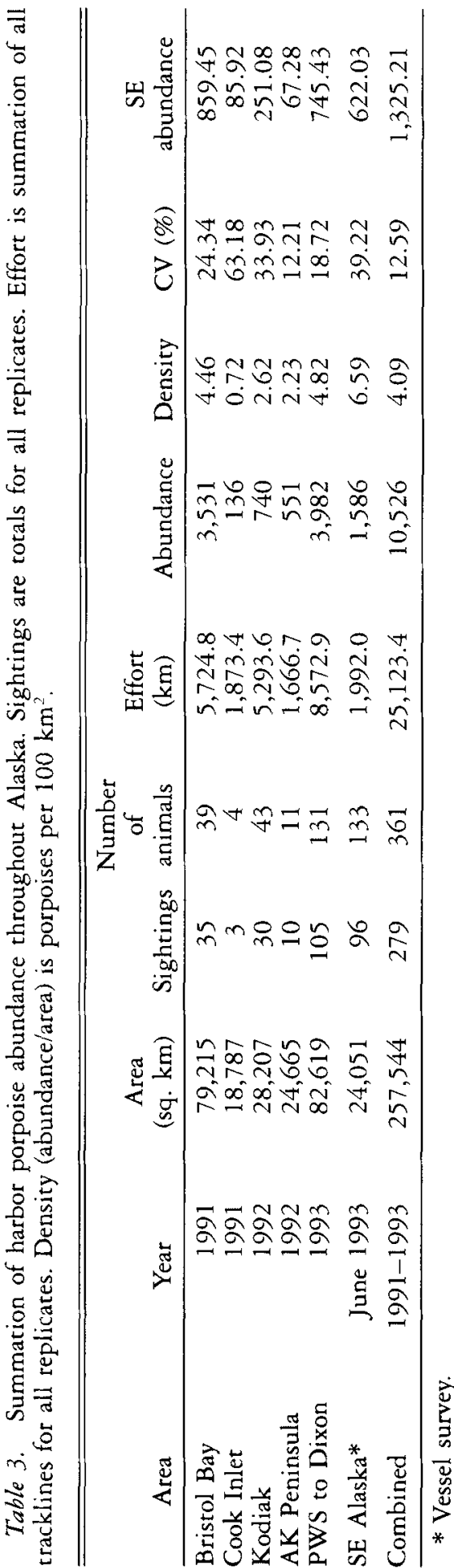




\section{Discussion}

To obtain reliable abundance estimates of harbor porpoise, observations and subsequent analysis must be limited to sightings collected during mild sea conditions and other optimal environmental conditions. During this study, field operations were terminated when whitecaps occurred (Beaufort 3). In Alaska, increasing sea state appeared to have the greatest effect on the ability of observers to detect porpoises. However, for areas outside of Alaska, many other environmental factors (e.g., percent of cloud cover, glare, and water clarity) have been shown to affect the sightability of this species from either the air or vessels (Barlow 1988, Barlow et al. 1988). Palka (1995a) was able to examine the influence of environmental factors (surface temperature, water depth, density index of prey species, and spatial location) on harbor porpoise distribution and abundance in the Gulf of Maine/Bay of Fundy region. She concluded that changes in abundance and distribution might be related to interannual changes in surface temperature and prey density.

Dohl et al. (1983) reported that harbor porpoises off California were generally found within $0.25 \mathrm{nmi}$ of the shoreline. Although water depth was not explicitly considered during our 1991-1993 studies, more effort was concentrated on nearshore areas.

The type of survey platform used has also been shown to affect population estimates (Barlow 1988, Barlow et al. 1988, Calambokidis et al. 1993). As expected, during aerial surveys, group size was undoubtedly underestimated, because the amount of time allowed to detect a second or third animal is extremely limited unless that animal is travelling very close to the initial animal sighted. Under good visibility conditions it is possible to detect porpoises below the surface, but this has not been quantified. Detection curves during our aerial surveys dropped off sharply at approximately $147 \mathrm{~m}$ (whereas the detection curve for the 1993 vessel survey dropped off at approximately 500 m, Dahlheim et al. 1994).

Kraus et al. (1983) compared sightability of harbor porpoises between aerial, vessel, and shore-based platforms. They concluded that aerial survey teams may miss $80 \%$ and vessel survey teams up to $50 \%$ of the harbor porpoise population in the viewing area. The group density estimates obtained during our aerial surveys (1991 through 1993) are lower than for our June 1993 vessel survey. While this is probably a function of the type of survey platform used, it might also reflect differences in abundance of porpoises between the two habitats. We cannot sort this out from the existing data.

The average density of harbor porpoises in Alaska appears lower that the estimates obtained for California, Oregon, and Washington (Barlow 1988, Barlow et al. 1988, Calambokidis et al. 1993). Given that survey conditions were ideal during most of our research, we conclude that the overall density of harbor porpoise is lower in Alaska waters. However, the distribution is no doubt patchy, with some areas having densities as great as those observed in California, Oregon, and Washington. In addition, our study, unlike previous studies, did not have an observer in a belly window, possibly contributing to 
lower observed encounter rates. Because few sightings were made during aerial surveys, we made the strong assumption that the detection curve estimated from the combination of sightings applied to all areas. Therefore, it is possible that the variance of the abundance estimate may be underestimated.

Our analysis indicates that group size is independent of sightability. Palka (1995b) also found no obvious size bias based on shipboard surveys in the northern Gulf of Maine and the lower Bay of Fundy in 1991.

The overall abundance estimate is biased downward because counts were not adjusted to account for missed porpoises on the trackline and because all areas of Alaska were not surveyed. Dedicated studies to address harbor porpoise behavior (e.g., percentage of missed animals on the trackline based on respiration rates, attraction versus avoidance of survey platform by porpoises, environmental affects on sightability of porpoises, etc.) have not been conducted in Alaska. To account for porpoises missed along the trackline, researchers working with harbor porpoises in California, Oregon, and Washington State have multiplied porpoise density values by a factor of 3.2 (Barlow et al. 1988, Calambokidis et al. 1993). If the Alaska estimates of harbor porpoises are multiplied by this most recent correction factor, an overall abundance estimate of 33,683 is obtained.

\section{ACKNOWLEDGMENTS}

Surveys of this magnitude could not have been completed without the help of many people. We thank our survey crews for their many hours of effort: R. Angliss, C. Goebel-Diaz, R. Hobbs, J. Lerczak, M. Merklein, M. Payne, L. Shaw, K. Shelden, P. Wade, and $\mathrm{K}$. Wynne. Our appreciation is extended to the crew of the NOAA Twin Otter. In particular, we wish to thank Lt. Cmd. Mike White, our pilot. The success of this 3-yr project is in large part due to Lt. Cmd. White's numerous contributions. He ensured that survey tracklines were flown efficiently and in optimal weather conditions, maximizing the amount of data collected and ensuring our safety. We thank $\mathrm{J}$. Barlow, S. Buckland, and J. Laake for aid in analysis and interpretation of the line transect data. This manuscript was improved by the reviews of Howard Braham, Jeff Laake, Doug DeMaster, Dave Rugh, Jim Lee, and Gary Duker.

\section{Literature Cited}

Barlow, J. 1988. Harbor porpoise, Phocoena phocoena, abundance estimation for California, Oregon, and Washington: I. Ship surveys. Fishery Bulletin, U.S. 86:417432.

Barlow, J., C. W. Oliver, T. D. Jackson and B. L. Taylor. 1988. Harbor porpoise, Phocoena phocoena, abundance estimation for California, Oregon, and Washington: II. Aerial surveys. Fishery Bulletin, U.S. 86:433-444.

Barlow, J., T. Eagle, S. Swartz and P. R. Wade. 1995. U.S. marine mammal stock assessments: Guidelines for preparation, background, and a summary of the 1995 assessments. NOAA Technical Memorandum NMFS-OPR-6. 73 pp. Available from Southwest Fisheries Science Center, P.O. Box 271, La Jolla, CA 92038.

Braham, H. W., L. L. Jones, G. C. Bouchet and A. T. Actor. 1983. Distribution and sightings of Dall's porpoise and harbor porpoise in the eastern North Pacific. Paper SC/35/SM1 8 presented at the 35th Meeting of the Scientific Committee, International Whaling Commission, Brighton, United Kingdom, June 1983. 
Available from National Marine Mammal Laboratory, 7600 Sand Point Way NE, Seattle, WA 98115.

BRUEGGEMAN, J. 1987. Aerial surveys of endangered cetaceans and other marine mammals in the northwestern Gulf of Alaska and southeastern Bering Sea. Report prepared for Minerals Management Service, Alaska OCS and NOAA. Contract No. 85-ABC-00093. 137 pp. Available from National Marine Mammal Laboratory, 7600 Sand Point Way NE, Seattle, WA 98115.

BRUEGGEMAN, J. 1988. Shipboard surveys for endangered cetaceans in the northwestern Gulf of Alaska. Report prepared for Minerals Management Service, Alaska OCS and NOAA. Contract No. 85-ABC-00093, 59 pp. Available from National Marine Mammal Laboratory, 7600 Sand Point Way NE, Seattle, WA 98115.

Bucki.And, S. T. 1985. Perpendicular distance models for line transect sampling. Biometrics 41:177-195.

Buckland, S. T., D. R. Anderson, K. P. Burnham and J. T. Laake. 1993. Distance sampling: estimating abundance of biological populations. Chapman and Hall, London, Glasgow.

Burnham, K. P., D. R. Anderson and J. L. Laake. 1980. Estimation of density from line transect sampling of biological populations. Wildlife Monograph No. 72. Supplement to Journal of Wildlife Management 44, 202 pp.

Calambokidis, J., J. C. Cubbage, S. J. Jeffries, P. J. Gearin and R. Brown. 1993. Harbor porpoise distribution and abundance off Washington as determined from aerial surveys in 1990. 32 p. Available from Cascadia Research Collective, 2181/2 West $4^{\text {th }}$ Avenue, Olympia, WA 98501.

Dahlifim, M., A. York, J. Waite and R. Towell. 1994. Abundance and distribution of harbor porpoise (Phocoena phocoena) in Southeast Alaska and the offshore waters of Dixon Entrance to Prince William Sound, 1993. Pages 20-40 in H. W. Braham and D. P. DeMaster, eds. Marine Mammal Assessment Program: Status of stocks and impacts of incidental take, 1993. Unpublished document available from $\mathrm{Na}$ tional Marine Mammal Laboratory, 7600 Sand Point Way NE, Seattle, WA 98115.

Dohl, T. P., R. C. Guess, M. L. Duman and R. C. Helm. 1983. Cetaceans of central and northern California, 1980-83: Status, abundance, and distribution. Report prepared for U.S. Minerals Management Service, contract \#14-12-0001-29090. Available from National Marine Mammal Laboratory, 7600 Sand Point Way NE, Seattle, WA 98115.

Fiscus, C. H., H. W. Braham, R. W. Mercer, R. D. Everitt, B. D. Krogman, P. D. McQuire, C. E. Peterson, R. M. Sonntag And D. E. Withrow. 1976. Seasonal distribution and relative abundance of marine mammals in the Gulf of Alaska. U.S. Department of Commerce, NOAA, Alaska Fisheries Center Processed Report, National Marine Fisheries Service. 238 pp. Available from National Marine Mammal Laboratory, 7600 Sand Point Way NE, Seattle, WA 98115.

Forsell, S. J., AND P. J. Gould. 1981. Distribution and abundance of marine birds and mammals wintering in the Kodiak area of Alaska. U. S. Department of the Interior Biological Survey Program FWS/OBS-81/13, Washington, DC. 72 pp. Available from National Marine Mammal Laboratory, 7600 Sand Point Way NE, Seattle, WA 98115.

GASKIN, D. E. 1983. The harbor porpoise: Regional populations, status and information on direct and indirect catches. Report of the International Whaling Commission 34:569-586.

HaLl, J. D. 1979. A survey of cetaceans of Prince William Sound and adjacent vicinity - their number and seasonal movements. OSCEAP Final Reports of Principal Investigators 6:681-726. Available from National Marine Mammal Laboratory, 7600 Sand Point Way NE, Seattle, WA 98115.

Kraus, S. D., J. R. Gilbert and J. H. Prescott. 1983. A comparison of aerial, ship- 
board, and land-based survey methodology for the harbor porpoise, Phocoena phocoena. Fishery Bulletin, U.S. 81:910-913.

LaAke, J. L., S. T. Buckland, D. R. Anderson and K. P. Burnham. 1993. DiSTANCE User's Guide V.2.O. Colorado Cooperative Fish and Wildlife Research Unit, Colorado State University, Fort Collins, CO.

Leather wood, S., and R. R. Releves. 1978. Porpoises and dolphins: Pages 97-111 in D. Haley, ed. Marine mammals of the eastern north Pacific and arctic waters. Pacific Search Press, Seattle, WA.

LeAtHerwood, S., A. E. Bowles ANd R. R. Reeves. 1983. Endangered whales of the eastern Bering Sea and Shelikof Strait, Alaska. Results of aerial surveys April 1982 through April 1983 with notes on other marine mammals seen. Hubbs Sea World Research Institute Technical Report No. 83-159, December 1983, 315 pp. Available from National Marine Mammal Laboratory, 7600 Sand Point Way NE, Seattle, WA 98115.

Lowry, L. F., K. J. Frost and J. J. Burns. 1982a. Investigations of marine mammals in the coastal zone of western Alaska during summer and autumn. Annual report on contract NA 81 RAC0050, submitted to NOAA, Outer Continental Shelf Environmental Assessment Program, Juneau, Alaska. 37 pp. Available from National Marine Mammal Laboratory, 7600 Sand Point Way NE, Seattle, WA 98115.

Lowry, L. F., K. J. Frost, D. G. Calkins, G. L. Swartzman and S. Hills. 1982b. Feeding habits, food requirements, and status of Bering Sea marine mammals. Volume 1, Text. Final report submitted to the North Pacific Fishery Management Council, Anchorage, Alaska. 292 pp. Available from National Marine Mammal Laboratory, 7600 Sand Point Way NE, Seattle, WA 98115.

MAtKIN, C. O., AND F. H. FAY. 1980. Marine mammal-fishery interactions on the Copper River and in Prince William Sound, Alaska, 1978. National Technical Information Services Report PN80-159536, 71 pp. Available from National Marine Mammal Laboratory, 7600 Sand Point Way NE, Seattle, WA 98115.

PALKA, D. 1995a. Influences on spatial patterns of Gulf of Maine harbor porpoise. Pages $69-75$ in A. S. Blix, L. Walløe and $\varnothing$. Ulltang, eds. Whales, seals, fish and man. Elsevier, Amsterdam.

PaLKa, D. 19956. Abundance estimate of the Gulf of Maine harbor porpoise. Report of the International Whaling Commission (Special Issue 16):27-50.

Rosel, P. E., A. E. Dizon And M. G. Haygood. 1995. Variability of the mitochondrial control region in populations of the harbor porpoise, Phocoena phocoena, on interocean and regional scales. Canadian Journal of Fisheries and Aquatic Sciences 52: $1210-1219$.

TAYLOR, B. L., AND P. K. DAwson. 1984. Seasonal changes in density and behavior of harbor porpoise (Phocoena pbocoena) affecting census methodology in Glacier Bay National Park, Alaska. Report of the International Whaling Commission 34:479483.

YURICK, D. B. 1977. Populations, sub-populations, and zoogeography of the harbor porpoise, Phocoena phocoena (L.). M.Sc. thesis, University of Guelph, Guelph, Ontario, Canada. 148 pp.

Received: 15 July 1996

Accepted: 12 January 1999 